\title{
Free insulin levels and metabolic effects of meal-time bolus and square-wave intraperitoneal insulin infusion in insulin-dependent diabetic patients
}

\author{
J.T.Jimenez, S. Walford, P. D. Home, I. Hanning and K. G. M. M. Alberti \\ Department of Medicine, University of Newcastle upon Tyne, UK
}

\begin{abstract}
Summary. The intraperitoneal route may offer more physiological insulin delivery through absorption of a proportion of the dose into the portal circulation. We have compared 1-h square-wave and bolus supplemental infusions of a fixed dose of $10 \mathrm{U}$ of intraperitoneal insulin in $6 \mathrm{C}$-peptide negative insulin-dependent diabetic patients eating a standard breakfast and compared the insulin, glucose and metabolite responses with those of non-diabetic control subjects. Blood glucose profiles were similar on the two experimental days and although the peak glucose levels were not different from normal they were delayed by $30 \mathrm{~min}(p<0.05)$. Basal free insulin levels were elevated in diabetic patients (square-wave 19.6 \pm 2.3 , bolus $18.7 \pm 1.9 \mathrm{mU} / \mathrm{l})$ compared to controls $(7.3 \pm 1.0 \mathrm{mU} / \mathrm{l}$, $p<0.02$ ) and rose more rapidly after bolus injection than infusion. Peak insulin concentration was achieved at $33 \pm 4 \mathrm{~min}$ after bolus, $90 \pm 13 \mathrm{~min}$ after infusion $(p<0.02)$ and $39 \pm$ $5 \mathrm{~min}$ in normal control subjects. The shape of the profile of
\end{abstract}

free insulin concentration was similar after bolus injection and in the controls, but after square-wave infusion the return to baseline was delayed $(p<0.05)$. Fasting intermediary metabolite concentrations were normal on both study days in the patients, but serum cortisol levels were significantly elevated and glucagon concentrations low. Metabolite responses to the meal were not significantly different from normal after bolus injection but increases in lactate and glycerol were seen at some time points between 60 and $180 \mathrm{~min}$ after infusion. Glucagon levels remained low after square-wave infusion. We conclude that bolus injection of the breakfast insulin supplement gives a more optimal profile of insulin delivery for patients on intraperitoneal insulin.

Key words: Intraperitoneal insulin, plasma insulin, insulin-dependent diabetes, intermediary metabolities.
In normal man insulin is secreted into the portal vein and a significant proportion is removed by the liver, leading to a marked portal-peripheral gradient [1]. By contrast, insulin is usually delivered peripherally in the treatment of insulin-dependent diabetes. Animal studies suggest that portal insulin delivery may be required to achieve metabolic normalisation in diabetes. The portal venous system is relatively inaccessible in man. However insulin is rapidly absorbed from the peritoneal cavity and there is some evidence to suggest that a proportion of the dose enters the portal circulation $[2,3]$.

Several studies have demonstrated that continuous intraperitoneal insulin infusion can be used to control insulin-dependent diabetes $[4,5]$ and is as effective yet safer than intravenous delivery for maintenance treatment of brittle diabetes $[6,7]$. Post-prandial excursions of blood glucose have been controlled in such patients by additional subcutaneous bolus injection [8], intraperitoneal square-wave infusions $[2,3]$ or intraperitoneal bolus injections [8, 9]. Only one brief report has addressed the question as to whether better metabolic control is obtained after a meal by bolus injection or square-wave infusion when insulin is given intraperitoneally [9]. This is important for the design of implantable infusion devices.

We have therefore compared the free insulin and metabolic profiles achieved with square-wave infusion or bolus injection of a fixed dose of intraperitoneal insulin followed by a standard breakfast in insulin-dependent diabetic subjects, and related these results to the insulin and metabolic profiles of non-diabetic control subjects in response to the same meal.

\section{Subjects and methods}

\section{Subjects}

Eight normal control subjects, mean age 30 years (range 23 to 43 ), weighing $70 \pm 3 \mathrm{~kg}$ (mean $\pm \mathrm{SD}$, body mass index $22 \pm 2$ ), were studied after an overnight fast. All were healthy men. 
Table 1. Clinical characteristics of the diabetic subjects

\begin{tabular}{|c|c|c|c|c|c|c|c|c|c|}
\hline $\begin{array}{l}\text { Patient } \\
\text { Number }\end{array}$ & $\begin{array}{l}\text { Age } \\
\text { (years) }\end{array}$ & $\begin{array}{l}\text { Weight } \\
(\mathrm{kg})\end{array}$ & $\begin{array}{l}\text { Height } \\
(\mathrm{cm})\end{array}$ & $\begin{array}{l}\text { Body mass } \\
\text { index }\end{array}$ & $\begin{array}{l}\text { Duration of } \\
\text { diabetes } \\
\text { (years) }\end{array}$ & $\begin{array}{l}\text { HbA1 } \\
(\%)\end{array}$ & $\begin{array}{l}\text { Normal SC } \\
\text { insulin } \\
(\text { dose } / 24 \text { h) }\end{array}$ & $\begin{array}{l}\text { Basal IP } \\
\text { insulin } \\
\text { (units } / h \text { ) }\end{array}$ & $\begin{array}{l}\text { Insulin } \\
\text { antibodies } \\
(\mu \mathrm{g} / \mathrm{l})\end{array}$ \\
\hline 2 & 28 & 66 & 160 & 25 & 14 & 11.0 & 60 & 1.0 & 6.2 \\
\hline 3 & 29 & 82 & 183 & 24 & 9 & 11.0 & 46 & 1.0 & 7.2 \\
\hline 4 & 30 & 76 & 178 & 24 & 18 & 9.0 & 36 & 0.75 & 22.2 \\
\hline Mean \pm SEM & $34 \pm 2$ & $75 \pm 3$ & $171 \pm 4$ & $25 \pm 1$ & $16 \pm 2$ & $10.2 \pm 0.4$ & $61 \pm 10$ & $1.0 \pm 0.1$ & \\
\hline Control & $30 \pm 2$ & $70 \pm 1$ & $178 \pm 1$ & $22 \pm 1$ & - & $\begin{array}{l}\text { Reference } \\
\text { range } 5.5-7.8\end{array}$ & - & - & $\begin{array}{l}\text { Normal } \\
\text { range }<2.0\end{array}$ \\
\hline
\end{tabular}

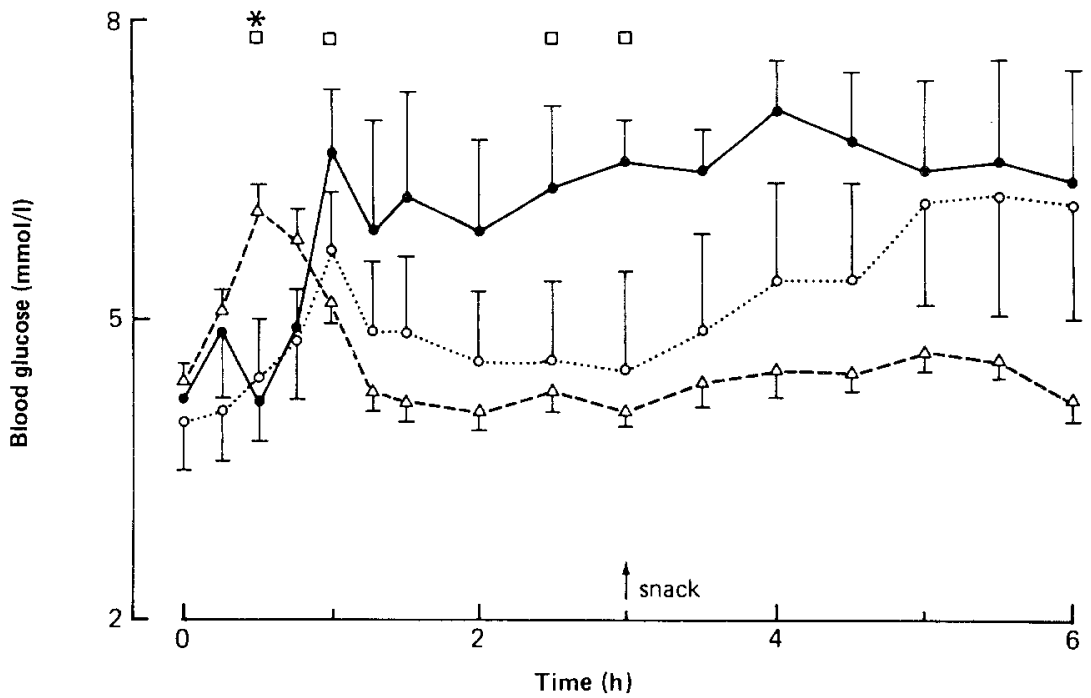

Fig. 1. Blood glucose response (mean \pm SEM) to a 40-g carbohydrate breakfast. $\triangle \longrightarrow \triangle$ normal controls, $O----O$ diabetic patients receiving a $10-\mathrm{U}$ bolus of intraperitoneal insulin, $\longrightarrow$ diabetic patients receiving a $10-\mathrm{U} 60$-min square-wave infusion of intraperitoneal insulin. ${ }^{*}, p<0.05$ bolus vs control; $\square, p<0.05$ infusion vs control

Six male insulin-dependent diabetic patients (Table 1 ), mean age 34 years (range 28 to 40 ), weighing $75 \pm 6 \mathrm{~kg}$ (body mass index $25 \pm 2$ ), were selected for study as being diabetic for more than 7 years (range 9 to 22 , mean $16 \pm 6$ years), free from major diabetic complications or other illness, having average blood glucose control by conventional criteria on twice daily mixtures of short and intermediate acting insulin preparations $\left(\mathrm{HbA}_{1} 10.2 \%, 9.0\right.$ to $11.0 \%$ (normal range 5.5 to $7.8 \%$ ), and having no detectable C-peptide response $60 \mathrm{~min}$ after a meal. They gave written consent to the study which was approved by the local ethical committee.

\section{Protocol}

The diabetic subjects were admitted to the investigation unit in the evening after having taken their normal dose of short acting insulin, but no intermediate or long acting insulin, prior to their normal meal at approximately $17.00 \mathrm{~h}$. A fine catheter (external diameter 0.7, internal $0.3 \mathrm{~mm}$, Siemens, Erlangen) was inserted $100 \mathrm{~mm}$ into the peritoneum under local anaethesia through a $50-\mathrm{mm} 18$ gauge Abbocath (Abbott Ireland, Dublin) in the mid-line $30 \mathrm{~mm}$ below the umbilicus, by a method similar to that of Schade and others [2]. The catheter was connected to a Promedos El infusion pump (Siemens, Erlangen) containing Hoechst CS acid soluble porcine insulin $40 \mathrm{U} / \mathrm{ml}$ (Hoechst, Hounslow), with an injection port incorporated into the catheter connections. The initial basal infusion rate calculated for $24 \mathrm{~h}$ was approximately $50 \%$ of the usual total daily insulin dose and was adjusted during the first night by hourly glucose monitoring so that by $06.00 \mathrm{~h}$ the blood glucose was stable between 3.5 and $6.0 \mathrm{mmol} / 1$, as measured with a Reflochek meter (Boehringer Mannheim, Mannheim) on capillary finger prick samples.
At $07.00 \mathrm{~h}$ a venous sampling cannula was inserted in the antecubital fossa and two basal samples were collected prior to commencing the study at $08.00 \mathrm{~h}$. The basal insulin infusion continued throughout the study.

As mealtime intraperitoneal insulin requirements were not known in these patients a fixed dose of the Hoechst insulin was given (10 U) either as a square-wave infusion over $1 \mathrm{~h}$ by the Promedos El pump, or by injection over $1 \mathrm{~min}$ into the injection port on the catheter. An identical breakfast containing $40 \mathrm{~g}$ carbohydrate, $17 \mathrm{~g}$ fat, $27 \mathrm{~g}$ protein, and approximately $400 \mathrm{kcal}$ in all was given in every experiment starting $5 \mathrm{~min}$ after the bolus injection and $15 \mathrm{~min}$ after the initiation of the square-wave. Control subjects had the same breakfast. Bolus and square-wave studies were performed in random order on consecutive mornings and no order effects were detected in the data, when checked by analysis of variance. Oral glucose was administered if the blood glucose fell below $2.5 \mathrm{mmol} / \mathrm{l}$. A 10 -g carbohydrate snack was given to the diabetic subjects $3 \mathrm{~h}$ after the start of the meal as a precaution against hypoglycaemia.

Blood samples for glucose and plasma free insulin were collected at $5 \mathrm{~min}$ intervals for $45 \mathrm{~min}$, every $15 \mathrm{~min}$ over the next hour, then half hourly for a further $4 \mathrm{~h}$. Free-flowing blood for intermediary metabolite analysis was collected every $15 \mathrm{~min}$ for the first $60 \mathrm{~min}$, and every $30 \mathrm{~min}$ thereafter. Glucagon, growth hormone and cortisol were measured at $0,30,90,180$ and $360 \mathrm{~min}$.

\section{Statistical analysis}

Data are shown as mean \pm SEM. Comparison between treatments was by Student's paired t-test, with no correction for multiple sampling in view of the non-independence of the data with time. Analysis 


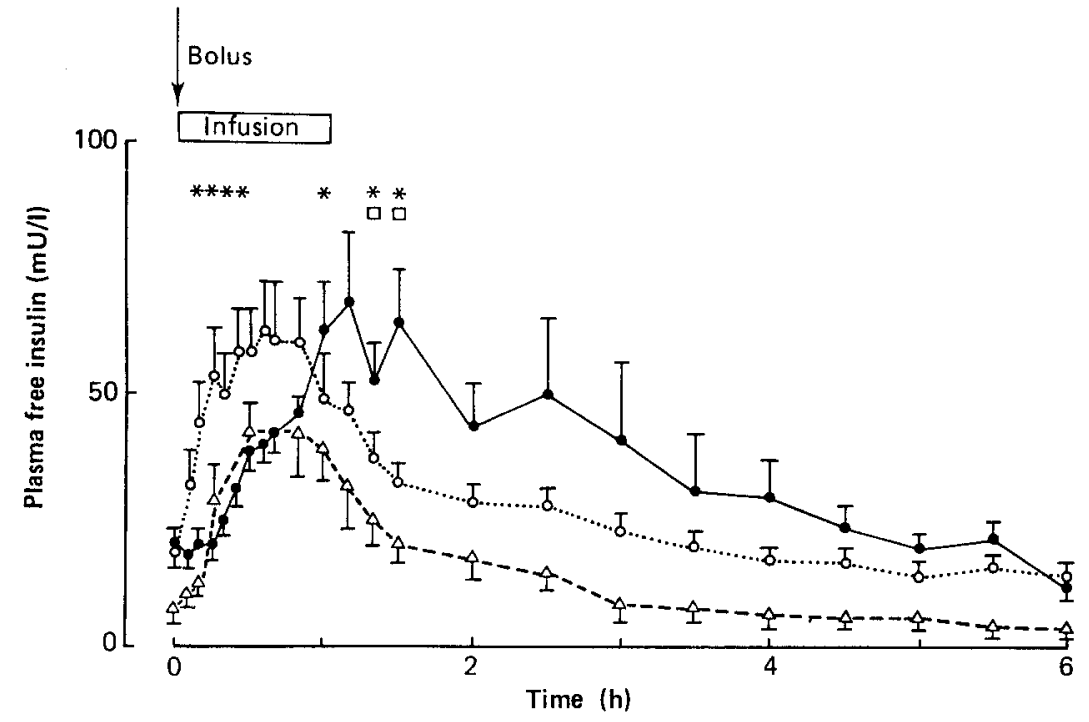

Fig. 2. Plasma free insulin profiles after bolus injection $(\mathrm{O}-\mathrm{O})$ or square-wave infusion $(-)$ ) of intraperitoneal insulin. Details as for Figure 1

Table 2. Intermediary metabolite response to breakfast

\begin{tabular}{|c|c|c|c|c|c|c|c|}
\hline $\begin{array}{l}\text { Blood metabolite } \\
(\mathrm{mmol} / 1 \pm \mathrm{SEM})\end{array}$ & & \multicolumn{6}{|l|}{ Time (min) } \\
\hline Lactate & $\begin{array}{l}\mathrm{N} \\
\mathrm{B} \\
\mathrm{I}\end{array}$ & $\begin{array}{l}0.73 \pm 0.08 \\
0.65 \pm 0.06 \\
0.62 \pm 0.04\end{array}$ & $\begin{array}{l}0.74 \pm 0.06 \\
0.64 \pm 0.09 \\
0.61 \pm 0.03\end{array}$ & $\begin{array}{l}0.89 \pm 0.07 \\
1.02 \pm 0.14 \\
0.87 \pm 0.10\end{array}$ & $\begin{array}{l}0.83 \pm 0.06 \\
0.99 \pm 0.13 \\
0.99 \pm 0.08\end{array}$ & $\begin{array}{l}0.70 \pm 0.05 \\
0.89 \pm 0.11 \\
0.93 \pm 0.09^{\mathrm{a}}\end{array}$ & $\begin{array}{l}0.60 \pm 0.04 \\
0.74 \pm 0.06 \\
0.83 \pm 0.07^{b}\end{array}$ \\
\hline Pyruvate & $\begin{array}{l}\text { N } \\
B \\
\text { I }\end{array}$ & $\begin{array}{l}0.068 \pm 0.009 \\
0.070 \pm 0.007 \\
0.062 \pm 0.006\end{array}$ & $\begin{array}{l}0.077 \pm 0.008 \\
0.078 \pm 0.010 \\
0.065 \pm 0.004\end{array}$ & $\begin{array}{l}0.088 \pm 0.008 \\
0.105 \pm 0.013 \\
0.091 \pm 0.008\end{array}$ & $\begin{array}{l}0.075 \pm 0.007 \\
0.096 \pm 0.010 \\
0.085 \pm 0.006\end{array}$ & $\begin{array}{l}0.068 \pm 0.006 \\
0.085 \pm 0.011 \\
0.083 \pm 0.010\end{array}$ & $\begin{array}{l}0.055 \pm 0.005 \\
0.069 \pm 0.006 \\
0.070 \pm 0.006\end{array}$ \\
\hline Alanine & $\begin{array}{l}\mathrm{N} \\
\mathrm{B} \\
\mathrm{I}\end{array}$ & $\begin{array}{l}0.29 \pm 0.02 \\
0.25 \pm 0.01 \\
0.24 \pm 0.02\end{array}$ & $\begin{array}{l}0.32 \pm 0.02 \\
0.26 \pm 0.01^{\mathrm{a}} \\
0.23 \pm 0.02^{\mathrm{b}}\end{array}$ & $\begin{array}{l}0.35 \pm 0.02 \\
0.30 \pm 0.01 \\
0.27 \pm 0.02^{\mathrm{a}}\end{array}$ & $\begin{array}{l}0.36 \pm 0.02 \\
0.34 \pm 0.02 \\
0.30 \pm 0.02\end{array}$ & $\begin{array}{l}0.36 \pm 0.02 \\
0.33 \pm 0.02 \\
0.31 \pm 0.02\end{array}$ & $\begin{array}{l}0.32 \pm 0.02 \\
0.32 \pm 0.01 \\
0.32 \pm 0.01\end{array}$ \\
\hline Glycerol & $\begin{array}{l}N \\
B \\
\text { I }\end{array}$ & $\begin{array}{l}0.043 \pm 0.004 \\
0.044 \pm 0.006 \\
0.058 \pm 0.006\end{array}$ & $\begin{array}{l}0.028 \pm 0.003 \\
0.029 \pm 0.009 \\
0.065 \pm 0.015^{\mathrm{b}}\end{array}$ & $\begin{array}{l}0.026 \pm 0.003 \\
0.026 \pm 0.002 \\
0.038 \pm 0.006\end{array}$ & $\begin{array}{l}0.023 \pm 0.002 \\
0.031 \pm 0.003 \\
0.037 \pm 0.006^{\mathrm{a}}\end{array}$ & $\begin{array}{l}0.026 \pm 0.002 \\
0.033 \pm 0.002 \\
0.040 \pm 0.004^{b}\end{array}$ & $\begin{array}{l}0.035 \pm 0.005 \\
0.042 \pm 0.004 \\
0.048 \pm 0.007\end{array}$ \\
\hline NEFA (plasma) & $\begin{array}{l}N \\
B \\
I\end{array}$ & $\begin{array}{l}0.60 \pm 0.05 \\
0.54 \pm 0.07 \\
0.76 \pm 0.07\end{array}$ & $\begin{array}{ll}0.47 & \pm 0.02 \\
0.58 & \pm 0.09 \\
0.77 & \pm 0.11^{\mathrm{a}}\end{array}$ & $\begin{array}{l}0.33 \pm 0.05 \\
0.46 \pm 0.06 \\
0.62 \pm 0.10\end{array}$ & $\begin{array}{l}0.35 \pm 0.02 \\
0.49 \pm 0.07 \\
0.53 \pm 0.07\end{array}$ & $\begin{array}{l}0.40 \pm 0.02 \\
0.50 \pm 0.08 \\
0.50 \pm 0.05\end{array}$ & $\begin{array}{l}0.45 \pm 0.04 \\
0.54 \pm 0.05 \\
0.60 \pm 0.06\end{array}$ \\
\hline
\end{tabular}

$\mathrm{N}=$ non-diabetic control; $\mathrm{B}=$ diabetic subjects after 10 - $\mathrm{U}$ bolus of intraperitoneal insulin; $\mathrm{I}=$ diabetic subjects after $10-\mathrm{U}$ square-wave infusion of intraperitoneal insulin. ${ }^{\mathrm{a}} p<0.05$ and ${ }^{\mathrm{b}} p<0.02$ compared to control

of variance was not used because of inhomogeneity of effects with time. Data from diabetic subjects was compared with control data by the unpaired Student's t-test. Area under the insulin curves was calculated by the trapezoidal rule from all time points.

\section{Assays}

Glucose was measured by a glucose oxidase method (Yellow Springs Analyser, Clandon Scientific, London). Plasma from the diabetic patients was extracted from insulin antibodies by precipitation at the time of venepuncture with polyethylene glycol $300 \mathrm{~g} / \mathrm{kg}$ in the assay buffer $[10,11,12]$. All samples from the study were assayed in one batch. Insulin from normal subjects was assayed on plasma directly. Direct insulin assay of normal plasma gave identical results to polyethylene glycol extracts in our assay [13]. Glucagon samples were collected in aprotinin/EDTA and immediately centrifuged and stored at $-20^{\circ} \mathrm{C}$ until assay by wick chromatography [14]. Cortisol and growth hormone were measured by radioimmunoassay on serum $[15,16]$. Metabolite samples were collected into weighed tubes containing chilled $0.5 \mathrm{~mol} / 1$ perchloric acid. Lactate, pyruvate, alanine, glycerol and 3-hydroxybutyrate were assayed using automated enzymatic fluorometric techniques [17] and plasma non-esterified fatty acid by a radio-cobalt dilution technique [18]. IgG specific insulin antibodies were assayed by a double antibody precipitation method [19] and Cpeptide by radioimmunoassay after ethanol extraction [20].

\section{Results}

\section{Blood glucose (Fig. 1)}

Fasting blood glucose in the diabetic patients did not differ from normal on either experimental day (presquare-wave $4.2 \pm 0.5$, pre-bolus $4.0 \pm 0.4$, control $4.4 \pm 0.1 \mathrm{mmol} / \mathrm{l}$ ). Peak blood glucose occurred $30 \mathrm{~min}$ after the start of the meal in controls $(6.1 \pm 0.3 \mathrm{mmol} / \mathrm{l})$ 
and was significantly higher than during either bolus or square-wave experiments at this time (bolus $4.4 \pm$ $0.6 \mathrm{mmol} / 1, \quad p<0.05$; square-wave $4.2 \pm 0.4 \mathrm{mmol} / 1$, $p<0.02$ ). Peak blood glucose levels occured $60 \mathrm{~min}$ after the start of the bolus study $(5.7 \pm 0.6 \mathrm{mmol} / \mathrm{l})$ and the square-wave infusion $(6.7 \pm 0.6 \mathrm{mmol} / 1)$, respectively 55 and $45 \mathrm{~min}$ after starting to eat. There were no significant differences in blood glucose profiles when the two methods of insulin delivery were compared, and in the
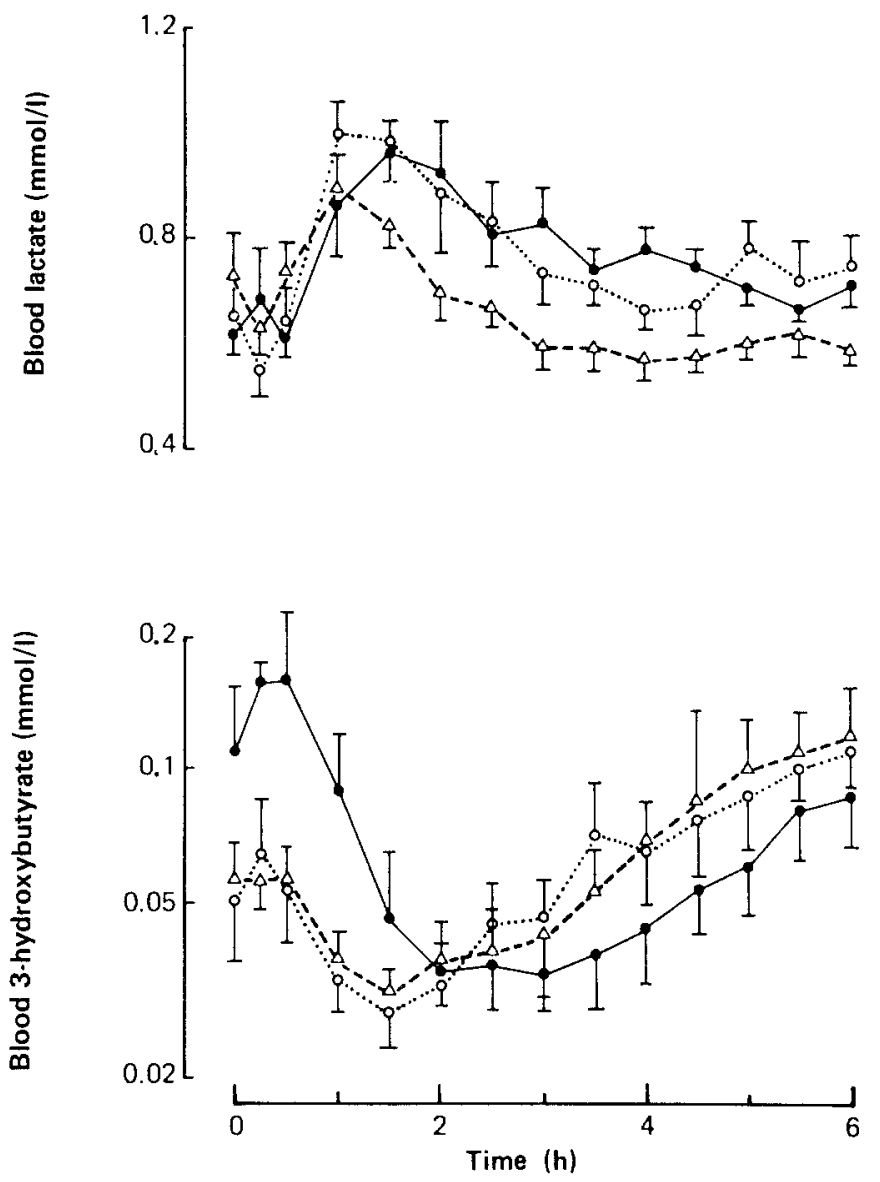

Fig. 3. Blood lactate (top panel) and 3-hydroxybutyrate concentrations after breakfast in diabetic patients given intraperitoneal insulin. Details as for Figure 1 bolus study glucose levels differed from normal only at $30 \mathrm{~min}(p<0.05)$. In contrast, glucose levels after square-wave infusion were significantly elevated at 60 , 150 and $180 \mathrm{~min}$. Later rises of blood glucose in diabetic subjects on both experimental days occurred after the snack given at $3 \mathrm{~h}$. Symptomatic hypoglycaemia occurred in one subject during both square-wave and bolus experiments at $90 \mathrm{~min}$.

\section{Free insulin profiles (Fig. 2)}

Diabetic subjects had similarly elevated fasting free insulin concentrations on both study days compared to non-diabetic controls (control $7.3 \pm 1.0 \mathrm{mU} / 1$; bolus $18.7 \pm 2.0 \mathrm{mU} / 1, p<0.01$; square-wave $19.6 \pm 2.3 \mathrm{mU} / 1$, $p<0.01)$. Peak insulin concentrations were achieved at $39 \pm 5 \mathrm{~min}$ by controls, and at $33 \pm 4 \mathrm{~min}$ after bolus injection, but the peak was significantly delayed after square-wave infusion to $90 \pm 13 \mathrm{~min}(p<0.02$ vs control or bolus). Free insulin profiles in the diabetic subjects after bolus injection continued to be significantly higher than controls from 10 to $25 \mathrm{~min}(p<0.05)$, and levels after square-wave infusion were significantly elevated at 60,90 and $105 \mathrm{~min}(p<0.05)$.

When the incremental changes in free insulin concentration were examined, concentrations after bolus injection differed significantly from normal controls only at $10 \mathrm{~min}(p<0.05)$. Insulin increased more slowly with square-wave infusion, lagging significantly behind bolus injection from 10 to $30 \mathrm{~min}(p<0.05)$, as well as normal controls at 15 and $30 \mathrm{~min}(p<0.02)$. Levels then fell more slowly compared to bolus and normal curves from 60 to $105 \mathrm{~min}(p<0.05)$ and with much greater variability. There was no significant difference between the incremental areas under the insulin curves in the diabetic subjects (injection $2820 \pm 634$, infusion $4590 \pm$ $1022 \mathrm{~min} \cdot \mathrm{mU} / \mathrm{l})$.

\section{Intermediary metabolites (Table 2)}

Fasting levels of lactate, pyruvate, alanine, glycerol, 3-hydroxybutyrate and NEFA were within the normal

Table 3. Hormone concentrations following breakfast

\begin{tabular}{|c|c|c|c|c|c|c|}
\hline Hormone \pm SEM & & \multicolumn{5}{|l|}{ Time (min) } \\
\hline Serum cortisol $(\mathrm{nmol} / \mathrm{l})$ & $\begin{array}{l}\mathrm{N} \\
\mathrm{B} \\
\mathrm{I}\end{array}$ & $\begin{array}{ll}274 & \pm 11 \\
425 & \pm 37^{\mathrm{b}} \\
460 & \pm 49^{\mathrm{b}}\end{array}$ & $\begin{array}{l}250 \pm 18 \\
328 \pm 9^{a} \\
308 \pm 30\end{array}$ & $\begin{array}{l}219 \pm 20 \\
266 \pm 21 \\
236 \pm 18\end{array}$ & $\begin{array}{l}189 \pm 9 \\
245 \pm 48 \\
194 \pm 28\end{array}$ & $\begin{array}{l}185 \pm 16 \\
176 \pm 29 \\
250 \pm 28\end{array}$ \\
\hline Growth hormone (iU/1) & $\begin{array}{l}\mathrm{N} \\
\mathrm{B} \\
\mathrm{I}\end{array}$ & $\begin{array}{l}1.4 \pm 0.2 \\
4.2 \pm 1.7 \\
7.7 \pm 4.1\end{array}$ & $\begin{array}{l}1.6 \pm 0.4 \\
2.2 \pm 0.5 \\
3.8 \pm 1.5\end{array}$ & $\begin{array}{l}1.1 \pm 0.1 \\
1.5 \pm 0.2 \\
1.7 \pm 0.3\end{array}$ & $\begin{array}{l}1.0 \pm 0.8 \\
7.4 \pm 5.0 \\
1.8 \pm 0.3\end{array}$ & $\begin{array}{l}5.4 \pm 1.9 \\
2.1 \pm 0.8 \\
7.3 \pm 4.4\end{array}$ \\
\hline Glucagon (ng/l) & $\begin{array}{l}\mathrm{N} \\
\mathrm{B} \\
\mathrm{I}\end{array}$ & $\begin{array}{l}42.0 \pm 7.3 \\
11.8 \pm 4.3^{b} \\
10.1 \pm 5.1^{b}\end{array}$ & $\begin{array}{l}30.0 \pm 9.9 \\
26.5 \pm 6.6 \\
23.5 \pm 6.5\end{array}$ & $\begin{array}{c}39.0 \pm 11.5 \\
13.6 \pm 7.0 \\
8.0 \pm 3.8^{a}\end{array}$ & $\begin{array}{l}56.0 \pm 15.6 \\
22.3 \pm 10.0 \\
10.1 \pm 3.1^{a}\end{array}$ & $\begin{array}{r}26.0 \pm 5.2 \\
8.6 \pm 6.2 \\
4.6 \pm 1.8^{\mathrm{a}}\end{array}$ \\
\hline
\end{tabular}

$\mathrm{N}=$ non-diabetic control; $\mathrm{B}=$ diabetic subjects after $10-\mathrm{U}$ bolus of intraperitoneal insulin; $\mathrm{I}=$ diabetic subjects after 10 - $\mathrm{U}$ square-wave infusion of intraperitoneal insulin. ${ }^{\mathrm{a}} p<0.05$ and ${ }^{\mathrm{b}} p<0.02$ compared to control 
range in every subject before each experiment. When the two insulin infusion protocols in the patients were compared all values were within the normal range in the first $3 \mathrm{~h}$ of the experiment (before the snack was given to the diabetic subjects). Glycerol levels rose in the first $30 \mathrm{~min}$ of the insulin infusion experiment and were significantly higher than levels after bolus injection which were falling at this time $(p<0.05)$. Compared to the normal response this difference was more significant $(p<$ 0.02 ), and glycerol again rose more rapidly than normal after infusion at 90 and $120 \mathrm{~min}$. In the infusion experiment NEFA levels also failed to suppress during the first $30 \mathrm{~min}(p<0.05)$ and alanine concentrations were significantly lower than normal at $30 \mathrm{~min}(p<0.02)$ and $60 \min (p<0.05)$. Lactate concentrations rose significantly at 120 and 180 min compared to normal controls.

In contrast the intermediary metabolite concentration after bolus injection differed from normal only at 30 min when alanine levels were lower $(p<0.05)$. Lactate and 3-hydroxybutyrate responses are shown in Figure 3.

More detailed analysis of the incremental changes in lactate concentration after the start of the meal shows that the rises in concentration were greater than normal in both experiments during the first hour $(p<0.05)$, but declined at the same rate thereafter.

\section{Hormones (Table 3)}

Fasting cortisol levels were significantly elevated in diabetic subjects on both experimental days, falling by $30 \mathrm{~min}$ with no significant differences from normals thereafter. Growth hormone levels showed no significant differences from normal.

Basal glucagon levels were significantly lower in diabetic subjects compared to normal and did not change significantly in either experiment.

\section{Discussion}

Intraperitoneal insulin delivery has been used successfully in the treatment of insulin-dependent diabetes [2, $6,8]$, and offers several potential advantages particularly because the insulin is rapidly absorbed with a porportion entering the portal circulation [3]. Even with very difficult diabetic patients intraperitoneal insulin therapy has been more effective and safer than continuous subcutaneous insulin infusion or long-term intravenous therapy $[6,7]$. Intraperitoneal insulin infusion would seem to offer advantages when used with implantable infusion devices, but in the design of such pumps it is important to determine whether meal-time insulin supplements would best be given as bolus injections or square-wave infusion.

The meal tests were performed after at least $12 \mathrm{~h}$ of overnight IP insulin delivery and the basal insulin infusion rate was undisturbed in the experiments. This tech- nique avoided any hiatus in insulin delivery which had complicated a previous study in which the change from peripheral to intraperitoneal insulin infusion was made just before the experiment [2]. Normal fasting blood glucose concentrations were achieved in all patients with basal insulin infusion rates between 0.75 and $1.25 \mathrm{U} / \mathrm{h}$, although basal free insulin concentrations were 2.5 times normal and approximately twice the levels found after IP infusion by Schade and others [4]. Fasting blood glucose levels in the patients reported in that study were however elevated above normal.

A fixed dose of $10 \mathrm{U}$ was arbitrarily chosen as the meal supplement to allow direct comparison of insulin profiles and was clearly excessive for the one patient whose basal requirement was $0.75 \mathrm{U} / \mathrm{h}$ and who became hypoglycaemic in both experiments. His data is retained in the study to avoid decreasing its power in respect of the insulin profiles, which in any case should be unaffected. Metabolic parameters after $90 \mathrm{~min}$ may be influenced by the glucose given to this patient at that time, but the disturbance should be equal in the two arms of the study.

The incremental changes in free insulin levels after bolus injection were strikingly similar to those seen in normal controls, and the decay part of the incremental insulin curve closely followed that of the normal subjects. In contrast the peak insulin response to squarewave infusion of the same dose was considerably delayed and declined more slowly with much greater variability. The areas under the incremental insulin curves are not significantly different. These will be affected by hepatic and peripheral clearance rates as well as insulin delivery into the circulation, and hence it is not necessarily appropriate that they were the same. The absorption of the intraperitoneal insulin bolus was much more rapid than seen in similar studies performed with subcutaneous insulin in normal subjects when peak insulin levels were not achieved until $75 \mathrm{~min}$ after the dose [21].

The differences in the insulin profiles seen in the two experiments did not give rise to any substantial differences in glucose or metabolite concentrations between the two modes of insulin delivery in the diabetic patients, but did lead to abnormalities in the levels of lactate, alanine, glycerol and NEFA in the patients receiving square-wave infusion when compared to the controls. While interpretation of the counter-regulatory hormone data is complicated by abnormalities at baseline, statistically these only peristed for glucagon within the infusion group (Table 3 ).

Peak blood glucose levels after the meal were not different in degree but were delayed by 15 to $30 \mathrm{~min}$ in both experiments. Square-wave infusion of insulin was also associated with failure of the blood glucose to return to basal levels. In comparison to similar data for glucose and insulin presented by Renner [9], we gave a rather larger proportion of the total daily insulin dose as a bolus and studied breakfast rather than lunch. They 
observed a similar delay in peak glucose after squarewave infusion and an initial fall in glucose levels after bolus injection not seen by us. Increments from basal to peak glucose in our studies were similar in both experiments and in controls, perhaps reflecting the slightly larger insulin doses. The responses on intraperitoneal bolus injection were closer to normal than those seen with peripheral intravenous insulin infusion from a Biostator [22] and in accord with the observation that intraportal but not intravenous insulin normalises intermediary metabolism and glucose carbon recycling in diabetic dogs $[23,24]$.

Since bolus infusion of intraperitoneal insulin produced free insulin, glucose and intermediary metabolite concentrations so similar to normal, we would conclude that this represents the more optimal profile for delivery of the breakfast insulin supplement for diabetic patients treated by intraperitoneal insulin infusion devices. This could in the long term prove to be the more general route of choice for insulin delivery in view of the failure to normalise intermediary metabolites with peripheral insulin delivery.

Acknowledgements. We are grateful to the British Diabetic Association and Novo Laboratories Limited for financial support, and to Dr. H.Orskov, Ms. L. Ashworth, Dr. A. Hodson and the staff of ward 15 Freeman Hospital for assistance and advice. PDH gratefully acknowledges the support of The Wellcome Trust and JTJ the National University of Asuncion, Paraguay.

\section{References}

1. WaldhäusI WK, Gasić S, Bratusch-Marrain P, Nowotny P (1983) The 75-g oral glucose tolerance test: effect on splanchnic metabolism of substrates and pancreatic hormone release in healthy man. Diabetologia 25:489-495

2. Schade DS, Eaton RP, Friedman N, Spencer WJ (1979) The intravenous, intraperitoneal and subcutaneous routes of insulin delivery in diabetic man. Diabetes 28: 1069-1072

3. Schade DS, Eaton RP, Davis T, Akiya F, Phinney E, Kubica R, Vaughn E, Day P (1981) The kinetics of peritoneal insulin absorption. Metabolism 30: 149-155

4. Schade DS, Eaton RP, Friedman N, Spencer W (1980) Normalisation of plasma insulin profiles with intraperitoneal insulin infusion in diabetic man. Diabetologia 19:35-39

5. Irsigler K, Kritz H (1980) Alternative routes of insulin delivery. Diabetes Care 3: 219-228

6. Selam JL, Slingeneyer A, Hedon B, Mares P, Beraud JJ, Mirouze J (1983) Long-term ambulatory peritoneal insulin infusion of brittle diabetes with portable pumps: comparison with intravenous and subcutaneous routes. Diabetes Care 6: 105-111

7. Husband DJ, Marshall SM, Walford S, Wright PD, Alberti KGMM (1984) Continuous intraperitoneal insulin infusion in the management of severely brittle diabetes - a metabolic and clinical comparison with intravenous infusion. Diabetic Med 1:99-104

8. Kritz $H$, Hagmüller E, Lovett $R$, Irsigler K (1983) Implanted constant basal rate insulin infusion devices for type 1 (insulin dependent) diabetic patients. Diabetologia 25: 78-81
9. Renner R, Piwernetz K, Hepp KD (1983) Continuous intraperitoneal insulin treatment in type 1 (insulin dependent) diabetes: comparison between square wave and bolus application. Diabetologia 25: 189 (Abstract)

10. Soeldner JS, Slone D (1965) Critical variables in the radio-immunoassay of serum insulin using the double antibody technic. Diabetes 14:771-779

11. Nakagawa $S$, Nakayama H, Sassaki A, Yoshino K, Yu Y, Shinozaki K, Aoki S, Mashimoto K (1973) A simple method for the determination of serum free insulin levels in insulin treated patients. Diabetes 22: $590-600$

12. Hanning I, Home PD, Alberti KGMM (1983) Measurement of "free" insulin. The influence of temperature, storage and duration of incubation on the desired result. Diabetologia 25: 161 (Abstract)

13. Hanning I, Home PD, Alberti KGMM (1985) Factors affecting the measurement of free insulin. Diabetic Med 2: 32 IA (Abstract)

14. Orskov H, Thomsen HG, Yde H (1968) Wick chromatography for rapid and reliable immunoassay of insulin, glucagon and growth hormone. Nature 219: 193-195

15. Boden G, Soeldner JS (1976) A sensitive double antibody radioimmunoassay for human growth hormone $(\mathrm{HGH})$; levels of serum HGH following tolbutamide infusion. Diabetologia 3: 413-421

16. Baum CK, Tudor T, London J (1974) A simple competitive protein binding assay for plasma cortisol. Clin Chim Acta 55:147-155

17. Lloyd B, Burrin J, Smythe P, Alberti KGMM (1978) Enzymic fluorometric continuous flow assays for blood glucose, lactate, pyruvate, alanine, glycerol and 3-hydroxybutyrate. Clin Chem 24: 1724- 1729

18. Ho RJ, Meng HC (1969) A simple and ultrasensitive method for determination of free fatty acid by radiochemical assay. Anal Biochem 31: 426-436

19. Reeves WG, Kelly U (1980) An immunochemical method for the quantitation of insulin antibodies. J Immunol Methods 34: $329-338$

20. Heding LG (1975) Radioimmunological determination of human C-peptide in serum. Diabetologia 11: 541-548

21. Home PD, Pickup JC, Keen H, Alberti KGMM, Parsons JA, Binder C (1981) Continuous subcutaneous insulin infusion: comparison of plasma insulin profiles after infusion or bolus injection of the meal-time dose. Metabolism 30: 439-442

22. Nosadini R, Noy GA, Nattrass M, Alberti KGMM, Johnston DG, Home PD, Orskov H (1982) The metabolic and hormonal response to acute normoglycaemia in type 1 (insulin-dependent) diabetes; studies with a glucose controlled insulin infusion system (artificial endocrine pancreas) Diabetologia 23:220-228

23. Stevenson RW, Parsons JA, Alberti KGMM (1981) Comparison of the metabolic response to portal and peripheral infusions of insulin in diabetic dogs. Metabolism 30: 745-752

24. Stevenson RW, Parsons JA, Alberti KGMM (1983) Effects of intraportal and peripheral insulin on glucose turnover and recycling in diabetic dogs. Am J Physiol 244: E190-E195

Received: 27 December 1984

and in revised form: 5 July 1985

\section{Dr. Philip Home}

Department of Medicine

Royal Victoria Infirmary

Newcastle upon Tyne NE14LP

UK 